\title{
Uji Antagonisme Bakteri Endofit dengan Cercospora oryzae Miyake dan Bipolaris oryzae (Breda de Haan) Shoemaker
}

\author{
Dinda Sekar Ayu Fiko', dan Fitri Widiantini² \\ ${ }^{1}$ PT. Syngenta Indonesia J1. TB Simatupang Jakarta Indonesia \\ ${ }^{2}$ Departemen Hama dan Penyakit Tumbuhan Fakultas Pertanian, Universitas Padjadjaran \\ Jl. Raya Bandung-Sumedang KM 21 Jatinangor Jawa Barat \\ Alamat korespondensi: fitri.widiantini@unpad.ac.id
}

\begin{abstract}
Antagonism test between Endophytic Bacteria and Cercospora oryzae and Bipolaris oryzae

Cercospora oryzae Miyake dan Bipolaris oryzae (Breda de Haan) Shoemaker are the causal agent of major disease for rice, which called Cercospora leaf spot and rice brown spot. Cercospora leaf spot and rice brown spot control using a bio-control agent in a form of endophytic bacteria is one of the eco-friendly alternative method. This research aimed to test the potential of the endophytic bacteria isolates which have the antagonism ability and able to reduce the growth of the diseases. The research was carried out in the Laboratory of Biotechnology Plant Protection of the Department of Plant Pests and Diseases, Faculty of Agriculture, Universitas Padjadjaran. The experiments were carried out using dual culture method. The experiments were performed using a completely randomized design (CDR) which consisted of 10 treatments with 4 replications. The antagonism experiments used 9 endophytic bacteria isolates from some parts of the rice plant. The result of antagonism of endophytic bacteria test showed that all of the isolates had antagonistic activity towards $C$. oryzae dan $B$. oryzae. Os6 isolate demonstrated the best result to inhibit $C$. oryzae growth with the radius of its colony reached only $85 \mathrm{~mm}$ and the inhibition growth percentage reached $85.83 \%$. Os3 isolate showed the best result to inhibit $B$. oryzae growth with the radius of its colony reached only $147.5 \mathrm{~mm}$ and the inhibition growth percentage reached $75.41 \%$.
\end{abstract}

Keywords: Inhibition growth, Cercospora leaf spot, Rice brown spot

\begin{abstract}
ABSTRAK
Cercospora oryzae Miyake dan Bipolaris oryzae (Breda de Haan) Shoemaker merupakan penyebab penyakit utama Padi, yaitu bercak daun Cercospora dan bercak coklat. Pengendalian $C$. oryzae dan $B$. oryzae dengan menggunakan agens hayati berupa bakteri endofit merupakan salah satu alternatif pengendalian yang ramah bagi lingkungan sekitar. Penelitian ini bertujuan untuk mengetahui potensi isolat bakteri endofit yang mempunyai kemampuan antagonis dan mampu menekan pertumbuhan penyakit. Penelitian ini dilaksanakan di Laboratorium Bioteknologi Proteksi Tanaman Departemen Hama dan Penyakit Tumbuhan, Fakultas Pertanian, Universitas Padjadjaran. Prosedur yang dilakukan adalah dual culture method. Percobaan dilakukan dengan menggunakan Rancangan Acak Lengkap (RAL) yang terdiri dari 10 perlakuan dengan masingmasing perlakuan diulang sebanyak 4 kali. Uji Antagonisme pada penelitian ini menggunakan 9 isolat bakteri endofit yang berasal dari beberapa bagian tanaman padi. Hasil penelitian menunjukkan bahwa 9 isolat bakteri endofit yang diujikan, semuanya bersifat antagonis terhadap C. oryzae dan B. oryzae. Isolat Os6 paling baik menghambat $C$. oryzae dengan jari-jari koloni sebesar $85 \mathrm{~mm}$ dan persentase penghambatan mencapai 85,83\%. Isolat Os3 paling baik menghambat $B$. oryzae dengan jari-jari koloni sebesar $147,5 \mathrm{~mm}$ dan persentase penghambatan mencapai $75,41 \%$.
\end{abstract}

Kata kunci: Penghambatan pertumbuhan, Bercak daun cercospora, Bercak coklat. 


\section{PENDAHULUAN}

Padi merupakan salah satu tanaman pangan pokok bagi sebagian besar negara di dunia. Lebih dari $50 \%$ penduduk dunia tergantung pada beras sebagai sumber kalori utama (Childs, 2004). Banyak faktor yang dapat menyebabkan turunnya produktivitas Padi, salah satunya adalah Organisme Pengganggu Tanaman (OPT). Cercospora oryzae Miyake dan Bipolaris oryzae (Breda de Haan) Shoemaker merupakan patogen penyebab penyakit bercak daun Cercospora dan bercak coklat, penyakit utama pada Padi. Penyakit bercak daun Cercospora dapat mengakibatkan daun padi menjadi kering sebelum waktunya sehingga berdampak buruk terhadap turunnya hasil panen tanaman padi dan juga dapat menyebabkan kerebahan tanaman padi (Semangun, 2004). Di Indonesia penyakit bercak daun Cercospora dapat menyebabkan penurunan hasil sebesar 40\% (Hollier, 1992).

Penyakit bercak coklat pada padi memiliki gejala bercak khas pada daun yang berbentuk oval, berukuran variatif, dan berbentuk seragam yang tersebar di seluruh permukaan daun. Bercak berwarna coklat dilingkari dengan warna abu, bagian tengah bercak bulat berwarna putih. Pada varietas yang peka, bercak akan lebih lebar, berukuran mencapai $1 \mathrm{~cm}$ atau lebih. Seringkali jumlah bercak memenuhi permukaan daun yang dapat mengakibatkan layu pada daun (Sudana, 1995). Serangan berat dapat secara signifikan mengurangi jumlah anakan dan bulir padi, serta menurunkan kualitas dan bobotnya. Kehilangan tersebut berkisar antara 30-43\% (Ou, 1985).

Penggunaan bakteri endofit adalah salah satu alternatif pengendalian penyakit bercak daun Cercospora dan bercak coklat yang aman bagi lingkungan. Bakteri endofit merupakan mikroorganisme menguntungkan yang hidup di dalam jaringan tanaman pada waktu tertentu dan mampu membentuk koloni serta berinteraksi dengan tanaman inang tanpa menyebabkan gangguan dan kerusakan pada tanaman tersebut (Zinniel et al., 2002).

Uji antagonis pada penelitian yang dilakukan oleh Kartini et al., 2014 menunjukkan bahwa dari 99 bakteri endofit yang diujikan, 57 diantaranya dapat menekan pertumbuhan patogen Erwinia sp. dengan mekanisme antibiosis. Mekanisme antibiosis berkaitan erat dengan kemampuan isolat bakteri endofit menghasilkan enzim dan senyawa lainnya. Enzim yang dihasilkan seperti kitinase, protease, dan selulase yang sangat berperan dalam menginduksi ketahanan tanaman (Hallmann et al., 1997). Bakteri endofit juga memproduksi zat pengatur pertumbuhan seperti auksin, etilen, dan sitokinin dan senyawa antimikrobial (Persello-Cartieaux et al., 2003). Penelitian ini bertujuan untuk untuk mengetahui potensi isolat bakteri endofit yang mempunyai kemampuan antagonis dan mampu menekan pertumbuhan penyakit bercak daun Cercospora dan bercak coklat.

\section{BAHAN DAN METODE}

Percobaan dilakukan di Laboratorium Bioteknologi Proteksi Tanaman, Departemen Hama dan Penyakit Tanaman, Fakultas Pertanian, Universitas Padjadjaran. Isolat bakteri endofit yang digunakan berjumlah 9 isolat yang berasal dari beberapa bagian tanaman padi dan biakan murni (patogen \& patogen) koleksi Laboratorium Bioteknologi Proteksi Tanaman, Fakultas Pertanian, Universitas Padjadjaran. Metode yang digunakan adalah metode dual culture.

\section{Perbanyakan C. oryzae Miyake dan B. oryzae (Breda de Haan) Shoemaker}

Perbanyakan patogen $C$. oryzae dan $B$. oryzae dilakukan dengan meletakkan plug biakan murni patogen $C$. oryzae dan $B$. oryzae pada media PDA. Media tersebut kemudian diinkubasikan selama 5 hari dalam suhu ruang.

\section{Perbanyakan Isolat Bakteri Endofit}

Perbanyakan dilakukan dengan mengambil 1 ose isolat dari isolat yang sudah ada, kemudian digoreskan ke media ISP2 padat dan diinkubasikan selama 3 hari pada suhu ruang. Isolat bakteri tersebut diperbanyak lagi dalam media ISP2 cair dengan mengambil 1 ose isolat dari isolat yang sudah diperbanyak kemudian dimasukkan ke dalam media ISP2 cair. Kemudian, campuran media ISP2 cair dengan isolat bakteri diinkubasikan pada suhu ruang dalam rotary shaking incubator dengan kecepatan 100 rpm selama 24 jam.

\section{Perhitungan Kerapatan Bakteri Endofit}

Kerapatan bakteri endofit dihitung menggunakan spectrophotometer pada isolat bakteri endofit yang telah dishaker selama 24 jam. Sebelumnya sudah diatur terlebih dahulu panjang gelombangnya yaitu OD600. Setelah beberapa saat, nilai kerapatan bakteri muncul pada spectrophotometer. Nilai $\mathrm{OD}_{600}=1$ setara dengan kerapatan sel bakteri $10^{7} \mathrm{CFU} / \mathrm{ml}$. 
Uji Antagonisme C. oryzae dan B. oryzae dan Bakteri Endofit

Eksperimen terdiri dari 10 perlakuan dan diulang sebanyak 4 kali yaitu terdiri dari:

A. Kontrol

B. Perlakuan dengan isolat bakteri endofit Os1

C. Perlakuan dengan isolat bakteri endofit Os2

D. Perlakuan dengan isolat bakteri endofit Os3

E. Perlakuan dengan isolat bakteri endofit Os4

F. Perlakuan dengan isolat bakteri endofit Os5

G. Perlakuan dengan isolat bakteri endofit Os6

H. Perlakuan dengan isolat bakteri endofit Os7

I. Perlakuan dengan isolat bakteri endofit Os8

J. Perlakuan dengan isolat bakteri endofit Os10

Pengujian antagonisme antara bakteri endofit terhadap jamur patogen $C$. oryzae dan $B$. oryzae dilakukan secara in vitro dalam cawan petri berjari-jari $9 \mathrm{~cm}$. Isolat bakteri endofit yang sudah dibiakkan pada media ISP2 padat diambil menggunakan jarum ose kemudian distreak pada cawan petri berisi media HPDA dengan jarak $3 \mathrm{~cm}$ dari bagian luar petri. Selanjutnya miselia jamur $C$. oryzae dan $B$. oryzae diambil menggunakan cork borrer ukuran $\pm 0,5 \mathrm{~mm}$ dan diletakkan di samping biakan bakteri endofit sebanyak satu titik per cawan petri dengan jarak $3 \mathrm{~cm}$ dari bagian luar petri. Seluruh cawan petri yang berisi perlakuan, diinkubasi pada suhu ruang selama 24 jam. Data yang diperoleh dianalisis dengan analisis sidik ragam (ANOVA) menggunakan SPSS 21, bila pengaruh rata-rata perlakuan tersebut berbeda nyata, maka dilakukan uji lanjut menggunakan Uji Jarak Berganda Duncan pada taraf 5\%.

\section{HASIL DAN PEMBAHASAN}

Hasil uji antagonisme menunjukkan bahwa 9 isolat bakteri yang diujikan memiliki sifat antagonis terhadap $C$. oryzae dan $B$. oryzae. Diameter koloni $C$. oryzae yang terbentuk berkisar antara 85-245 mm (Tabel 1) dan diameter koloni $B$. oryzae yang terbentuk berkisar antara 147,5-465 $\mathrm{mm}$ (Tabel 2). Berdasarkan pengamatan, isolat Os6 merupakan isolat terbaik dibandingkan dengan perlakuan lainnya dalam menghambat pertumbuhan koloni $C$. oryzae. Terlihat dari koloni jamur patogen yang terbentuk hanya mencapai $85 \mathrm{~mm}$. Hal ini juga didukung oleh persentase penghambatan isolat Os6 yang tinggi mencapai 85,83\% (Tabel 1).

Pengamatan pada uji antagonisme antara $B$. oryzae dan bakteri endofit menunjukkan bahwa isolat Os3 merupakan isolat terbaik dibandingkan dengan perlakuan lainnya dalam menghambat pertumbuhan jamur tersebut. Koloni B. oryzae yang terbentuk hanya mencapai $147,5 \mathrm{~mm}$ dengan persentase penghambatan sebesar 75,41\% (Tabel 2).

Tabel 1. Hasil uji antagonisme antara C. oryzae dan bakteri endofit

\begin{tabular}{ccc}
\hline Perlakuan & $\begin{array}{c}\text { Diameter } \\
\text { Koloni (mm) }\end{array}$ & $\begin{array}{c}\text { Persentase } \\
\text { Penghambatan (\%) }\end{array}$ \\
\hline Os1 & $245 \mathrm{~d}$ & 59,16 \\
Os2 & $217,5 \mathrm{c}$ & 63,75 \\
Os3 & $142,5 \mathrm{~b}$ & 76,25 \\
Os4 & $127,5 \mathrm{~b}$ & 78,75 \\
Os5 & $195 \mathrm{c}$ & 67,50 \\
Os6 & $85 \mathrm{a}$ & 85,83 \\
Os7 & $120 \mathrm{~b}$ & 80,00 \\
Os8 & $210 \mathrm{c}$ & 65,00 \\
Os10 & $137,5 \mathrm{~b}$ & 77,08 \\
Kontrol & $600 \mathrm{e}$ & - \\
\hline
\end{tabular}

Tabel 2. Hasil uji antagonisme antara B. oryzae dan bakteri endofit

\begin{tabular}{ccc}
\hline Perlakuan & $\begin{array}{c}\text { Diameter } \\
\text { Koloni }(\mathrm{mm})\end{array}$ & $\begin{array}{c}\text { Persentase } \\
\text { Penghambatan (\%) }\end{array}$ \\
\hline Os1 & $187,5 \mathrm{a}$ & 68,75 \\
Os2 & $285 \mathrm{~b}$ & 52,50 \\
Os3 & $147,5 \mathrm{a}$ & 75,41 \\
Os4 & $202,5 \mathrm{a}$ & 66,25 \\
Os5 & $357,5 \mathrm{c}$ & 40,41 \\
Os6 & $160 \mathrm{a}$ & 73,33 \\
Os7 & $180 \mathrm{a}$ & 70,00 \\
Os8 & $372,5 \mathrm{c}$ & 39,16 \\
Os10 & $465 \mathrm{~d}$ & 22,50 \\
Kontrol & $600 \mathrm{e}$ & - \\
\hline
\end{tabular}

Terdapat beberapa mekanisme penekanan pertumbuhan patogen yang dilakukan oleh agens antagonis, salah satunya adalah mekanisme antibiosis (Compant et al., 2005). Mekanisme penghambatan yang terjadi pada isolat Os6 dan Os3 diduga merupakan mekanisme antibiosis. Mekanisme antibiosis merupakan penghambatan patogen oleh senyawa metabolik yang dihasilkan oleh agensia hayati seperti enzim, senyawa-senyawa volatile, zat pelisis dan senyawa antibiotik lainnya (Nurhayati, 2011). Agens antagonis menghasilkan senyawa antibiotik yang bersifat menghambat atau membunuh patogen, sehingga terdapat daerah tertentu yang tidak ditumbuhi oleh patogen (Nawangsih, 2007). Senyawa antibiotik dapat mengakibatkan terjadinya endolisis atau autolisis, yaitu pecahnya sitoplasma suatu sel oleh enzim yang 
diikuti kematian sel yang mungkin disebabkan kekurangan hara, antibiotik ataupun kerusakan dinding sel (Baker \& Cook, 1982). Mikroorganisme pengendali hayati seperti bakteri dan jamur dapat menghasilkan beberapa senyawa bioaktif seperti antibiotik yaitu eritromisin, tetrasiklin, streotimisin, nistatin, neomisin, kanamisin, sikloheksimida, sikloserin, linkomisin, aminoglikosida, aureomisin, kloramfenikol, nistatin, amphoterisin dan amfosetin B (Purnomo et al. 2005; Madigan et al. 2006). Selain senyawa bioaktif seperti antibiotik, agens antagonis juga menghasilkan enzim hidrolitik (protease, kitinase, selulase, lipase) dan inhibitor enzim (Papuangan, 2009; Syamsuddin et al., 2007).
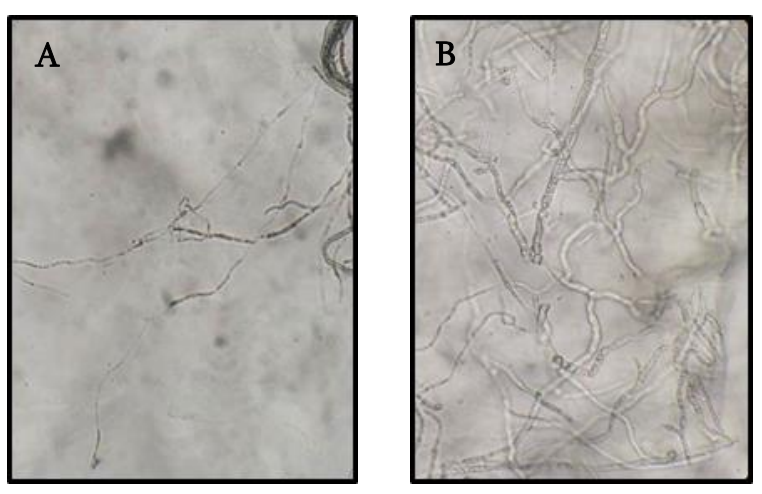

Gambar 1. (A) Hifa $C$. oryzae mengalami perataan; mengalami melanisasi dan pembengkakan;
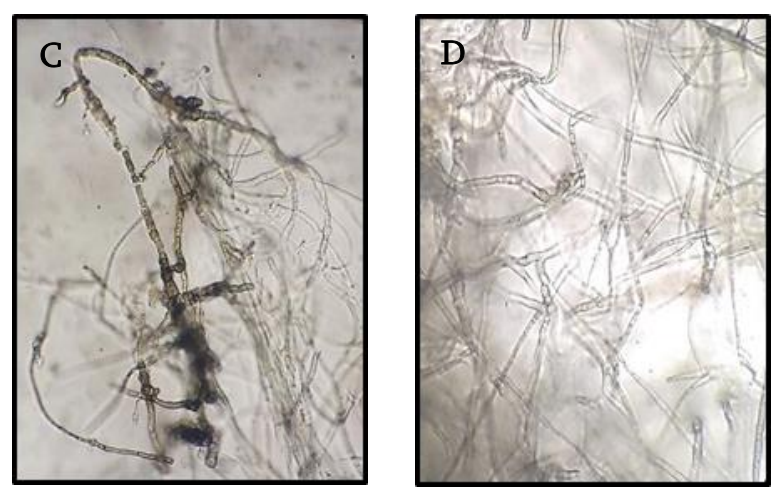

(B) Hifa $C$. oryzae mengeriting; (C) Hifa $C$. oryzae (D) Hifa $B$. oryzae mengeriting.
Hasil pengamatan mikroskopis menunjukkan bahwa hifa $C$. oryzae dan $B$. oryzae pada perlakuan kontrol tumbuh dengan normal. Pada perlakuan Os, hifa $C$. oryzae dan B. oryzae dihambat pertumbuhannya dan mengalami ketidaknormalan morfologi seperti flattening, mengeriting (curling), melanisasi, dan pembengkakan (swollen) (Gambar 1).

Abnormalitas hifa jamur akibat perlakuan dengan agens antagonis yang umum ditemukan antara lain pembengkokan ujung miselium dan miselium pecah (Lorito et al., 1993). Selain itu terdapat abnormalitas hifa dengan terjadinya melanisasi pada hifa. Melanisasi merupakan proses pembentukan melanin yang dilakukan oleh organisme termasuk patogen jamur untuk bertahan hidup dari cekaman lingkungan (Henson et al., 1999). Melanin berperan terhadap virulensi suatu patogen untuk bertahan dari mekanisme pertahanan yang dilakukan oleh tanaman yang bersifat anti mikroba (Nosanchuk \& Casadeval 2006). Pada isolatisolat bakteri endofit yang diujikan diduga menghasilkan senyawa antifungal yang membuat lingkungan menjadi tidak optimal bagi pertumbuhan $C$. oryzae dan $B$. oryzae, sehingga mengalami proses melanisasi untuk mempertahankan diri.

\section{SIMPULAN}

Sebanyak 9 isolat bakteri endofit yang diujikan memiliki daya antagonis terhadap $C$. oryzae dan $B$. oryzae. Isolat Os6 adalah yang terbaik dalam menghambat pertumbuhan $C$. oryzae dengan koloni jamur patogen yang terbentuk sebesar $85 \mathrm{~mm}$ dan persentase penghambatan sebesar $85,83 \%$. Isolat Os3 adalah yang terbaik dalam menghambat pertumbuhan $B$. oryzae dengan koloni jamur patogen yang terbentuk sebesar 147,5 $\mathrm{mm}$ dan persentase penghambatan sebesar $75,41 \%$.

\section{DAFTAR PUSTAKA}

Baker, KF dan RJ Cook. 1982. Biological control of plant pathogens. The American Phytopathology Society. Minnessota Fravel.

Childs, WN. 2004. Production dan Utilization of Rice. U.S Department of Agriculture. Economic Research Service. Washington DC.

Compant S, B Reiter, A Sessitsch, J Nowak, C Clément dan EA Barka, 2005. Endophytic colonization of Vitis vinifera L. by plant rowth-promoting bacterium Burkholderia sp. strain PsJN. Applied and Environmental Microbiology. 71 (16): 85-93.

Hallmann, J. 2001. Plant Interaction with Endophytic Bacteria. Biotic Interaction in Plant-Patogen Association. CAB International.

Henson, JM, MJ Butler, and AW Day. 1999. The dark side of te mycelium Melanins of 
phytopathogenic fungi. Annu Rev. Phytopathology. 37:447-471.

Hollier, C. 1992. Narrow brown leaf spot. P. 18 in Compendium of Rice Diseases (RK Webster \& PS Gunnell, eds.). APS Press, St. Paul, $\mathrm{MN}$.

Kartini, E, AL Abadi, dan LQ Aini. 2014. Pengembangan bio-bakterisida yang memanfaatkan bahan aktif bakteri endofit potensial antagonis untuk mengendalikan Erwinia sp., di umbi kentang. Jurnal Hama dan Penyakit Tumbuhan. 2(4).

Lorito, M, GE Harman, CK Hayes, RM Broadway, A Tronsmo, C Peterbauer and A Di Pietro. 1993. Chitinolytic Enzymes Produced by Trichoderma harzianum: Purified Endochitinase and Chitobiosidase. Phytopathology 83 (3): 313-318.

Madigan MT, JM Martinko, and J Parker. 2006. Brock: Biology of Mikroorganims. New Jersey American: Prentice Hall.

Nawangsih, AA. 2007. Pemanfaatan Bakteri Endofit pada Pisang untuk Mengendalikan Penyakit Darah: Isolasi, Uji Penghambatan In Vitro dan In Planta. Jurnal Ilmu Pertanian Indonesia 12 (1): 43-49.

Nosanchuk, JD and A Casadevall. 2006. Impact of melanin on microbial virulence and clinical resistance to antimicrobial compounds antimicrobial agents and chemotherapy. 50 (11): 1723-1727

Nurhayati. 2011. Penggunaan jamur dan bakteri dalam pengendalian penyakit tanaman secara hayati yang ramah lingkungan. Prosiding Semirata Bidang Ilmu-ilmu
Pertanian BKS-PTN Wilaya Barat. Sumatera Selatan.

Ou, SH. 1985. Rice Diseases 2nd edn. CMI, Kew, England.

Papuangan, N. 2009. Aktivitas Penghambatan Senyawa Antimikrob Streptomyces spp. Terhadap Mikrob Patogen Tular Tanah Secara In Vitro dan In Planta. Institut Pertanian Bogor. Thesis.

Persello-Cartieaux, F, L Nussaume, and C Robaglia. 2003. Tales from the Underground: Molecular plant-rhizobacteria interactions. Plant, Cell and Environment 26 (2): 99-189.

Purnomo AT, M Lailiana, dan Isnaeni. 2005. Aktivitas antibakteri sel amobil Streptomyces Sp-1 dalam matrik Ca-alginat dan Ba-alginat Staphylococcus aureus. Maj Farmasi Airlangga, 5 (2).

Semangun, H. 2004. Penyakit-penyakit Tanaman Perkebunan di Indonesia. UGM Press.Yogyakarta.

Sudana, S. 1995. Pengendalian Terpadu Hama Penyakit dan Gulma Padi. Kanisius Yogyakarta.

Syamsuddin, S. Ilyas, Alfizar dan B Amin. 2007. Pengembangan Bioogical Seed Treatment untuk Pengendalian Busuk Phytopthora pada Cabai Merah (Capsicum annum L.) Hibah bersaing XIV Perguruan Tinggi.

Zinniel, DK, PA Lambrecth, NB Harris, Z Feng \& D Kuczmarski. 2002. Isolation and characterization of endophytic colonizing bacteria from agronomic crops and prairie plants. Applied Enviromental Microbiology. 68: 2198-2208. 